\title{
EFFECTS OF PATIENT AND PHYSIOTERAPIST CHARACTERISTICS ON PERCEIVED QUALITY OF PHYSIOTHERAPY CARE AT DR. MOEWARDI HOSPITAL, SURAKARTA
}

\author{
Afif Ghufroni ${ }^{1,2)}$, Rita Benya Adriani²), Didik Gunawan Tamtomo ${ }^{1)}$ \\ 1)Masters Program on Public Health, Sebelas Maret University \\ 2)School of Health Polytechnics, Surakarta
}

Background: Nowadays patients demand quality and safe hospital care. Quality of care depends on the roles of the government as quality of care regulator, hospital management, health care providers, patients, and the community. The study aimed to examine the effects of patient and physioterapist characteristics on perceived quality of physiotherapy care.

Subjects and Method: This was an observational analytic study with crosssectional design. The study was conducted at Dr. Moewardi Hospital, Surakarta, Central Java, from June to July, 2017. A total sample of 122 physiotherapy patients were selected for this study using exhaustive sampling. The dependent variable was quality of physiotherapy care. The independent variables were patient's education and income, duration of treatment, insurance status, years of services, physiotherapist training, and salary. The data were collected using a set of questionnaire and analyzed by multiple linier regression.

Results: The quality of physiotherapist care was affected by patient's income $(\mathrm{b}=-0.18 ; 95 \% \mathrm{CI}=-0.35$ to $0.001 ; \mathrm{p}=0.052)$, patients education $(\mathrm{b}=-3.32$; $95 \% \mathrm{CI}=-6.59$ to $0.04 ; \mathrm{p}=0.047)$, duration of treatment $(\mathrm{b}=-0.07 ; 95 \% \mathrm{CI}=-$ 0.14 to $-0.01 ; \mathrm{p}=0.020)$, insurance status $(\mathrm{b}=3.41 ; 95 \% \mathrm{CI}=0.15$ to $6.68 ; \mathrm{p}=$ 0.041), years of services $(b=0.55 ; 95 \% \mathrm{CI}=0.15$ to $0.97 ; \mathrm{p}=0.010)$, physiotherapist training $(\mathrm{b}=0.90 ; 95 \% \mathrm{CI}=0.09$ to $1.71 ; \mathrm{p}=0.030)$, and salary $(b=0.38 ; 95 \% \mathrm{CI}=-0.12$ to $0.77 ; \mathrm{p}=0.061)$.

Conclusion: Quality of physiotherapist care is affected by patient's income, patients education, duration of treatment, insurance status, years of services, physiotherapist training, and salary.

Keywords: quality of care, physiotherapy, insurance status, duration of treatment, years of services

Correspondence: Afif Ghufroni. School of Health Polytechnics, Surakarta, Central Java. Email: apip.physio@gmail.com. Mobile: +6285725000769. 